\title{
Anthelmintic effect of Cassia fistula and Combretum leprosum protein fractions against goat gastrointestinal nematodes
}

\author{
Efeito antihelmíntico das frações proteicas de Cassia fistula e Combretum leprosum contra nematodeos \\ gastrintestinais de caprinos \\ Mara Thais de Oliveira Silva ${ }^{1 *}$; Mara Andrade Colares Maia ${ }^{1}$; Michele Dalvina Correia da Silva²; \\ Taffarel Melo Torres²; José Carlos da Silveira Pereira²; João Ronielly Campêlo Araújo ${ }^{3}$; Ryan Emiliano da Silva²; \\ Anna Lopes da Costa Souza ${ }^{2}$; Tallyson Nogueira Barbosa²; Ana Carla Diógenes Suassuna Bezerra ${ }^{2}$ \\ ${ }^{1}$ Centro de Desenvolvimento Tecnológico, Universidade Federal de Pelotas - UFPel, Pelotas RS, Brasil \\ ${ }^{2}$ Centro de Ciências Biológicas e da Saúde, Universidade Federal Rural do Semi-Árido - UFERSA, Mossoró RN, Brasil \\ ${ }^{3}$ Departamento de Bioquímica e Biologia Molecular, Universidade Federal do Ceará - UFC, Fortaleza, CE, Brasil
}

Received October 31, 2017

Accepted May 3, 2018

\begin{abstract}
In this study, we evaluated the ovicidal and larvicidal activity of protein preparations obtained from Cassia fistula $\mathrm{L}$. and Combretum leprosum Mart. leaves on the gastrointestinal parasites of goats. Protein preparations were obtained after the extraction of $C$. fistula $\mathrm{L}$. and $C$. leprosum Mart. leaves, followed by protein fractionation (with ammonium sulfate saturation percentages of $30 \%, 30 \%-60 \%$, and 60\%-90\%) and dialysis, which resulted in protein fractions (called F1, F2, and F3, respectively). The fractions were evaluated by egg hatching (the eggs were recovered in stool samples from naturally infected goats) and larval development tests. The results reveled that the inhibition of hatching of eggs caused by the protein fractions of $C$. fistula (38\%) were similar to that of the control drug, thiabendazole. In addition, the fractions of C. fistula caused significant inhibition (61-69\%) of larval development also. However, C. leprosum did not reveal significant inhibition of egg hatching and larval development. We conclude that $C$. fistula L. showed better ovicidal and larvicidal activity against endoparasites.
\end{abstract}

Keywords: Phytotherapy, Cassia fistula L., Combretum leprosum Mart., larvicidal activity, ovicidal activity.

\section{Resumo}

Neste estudo, foram avaliadas as atividades ovicida e larvicida de preparaçóes proteicas de Cassia fistula L. e Combretum leprosum Mart. em parasitas gastrointestinais de caprinos. As preparações proteicas foram obtidas por extração das folhas de C. fistula L. e C. leprosum Mart. seguido pelo fracionamento proteico (com porcentagens de saturação de sulfato de amônio de 30\%, 30-60\%, 60-90\%) e diálise, resultando nas fraçôes proteicas (intituladas F1, F2 e F3, respectivamente). As frações foram avaliadas nos testes de eclosão de ovos (os ovos foram recuperados em amostras de fezes de cabras naturalmente infectadas) e de desenvolvimento larvar. Os resultados revelaram que a inibição da eclosão de ovos causada pelas fraçóes proteicas de C. fistula (38\%) foi semelhante à do fármaco controle, o tiabendazol. Além disso, as fraçôes de C. fistula também causaram inibição significativa (61-69\%) do desenvolvimento larvar. No entanto, C. leprosum não revelou inibiçấo significativa na eclosão dos ovos e no desenvolvimento larvar. Concluiu-se que C. fistula L. mostrou uma melhor atividade ovicida e larvicida contra endoparasitas.

Palavras-chave: Fitoterapia, Cassia fistula L., Combretum leprosum Mart., atividade larvicida, atividade ovicida.

\section{Introduction}

Goat breeding is an extremely important activity that constitutes a vital element of the economy in Latin America; however, this industry has been limited by gastrointestinal parasitism

*Corresponding author: Mara Thais de Oliveira Silva. Laboratório de Biotecnologia Infecto-Parasitária, Centro de Desenvolvimento Tecnológico, Universidade Federal de Pelotas - UFPel, Campus Universitário, s/n, Prédio 19, CEP 96010-900, Pelotas, RS, Brasil. e-mail: marathaisos@gmail.com
(MARIE-MAGDELEINE et al., 2014), where the emphasis is on the gastrointestinal nematode Haemonchus contortus due to its high prevalence and pathogenicity. Control methods based exclusively on the use of anthelmintics have led to the emergence of parasite resistance (MOLENTO et al., 2011). In this context, new alternatives of treatment are being researched to control those nematodes, such as the use of phytotherapeutic agents (which are found in various Latin American regions). 
In the semiarid region of Northeast Brazil, the Caatinga biome is seen as a region of great plant diversity with yet unexplored biological potential (ALBUQUERQUE et al., 2007). In the present study, Cassia fistula L. and Combretum leprosum Mart. are evaluated. The first belongs to a genus with potential anthelmintic activity, as demonstrated by the species Cassia occidentalis and $C$. alata (ADEMOLA \& ELOFF, 2011), and its activity is influenced by the presence of compounds like triterpenes and flavonoid derivatives (KASHIWADA et al., 1990). The methanolic extract of $C$. fistula leaves has also demonstrated ovicidal and larvicidal activity against Culex quinquefasciatus and Anopheles stephensi (GOVINDARAJAN et al., 2008). In addition, the ethanolic extract of leaves of this species completely inhibited eggs hatching in Rhipicephalus (Boophilus) annulatus when applied in high concentrations of $80 \mathrm{mg} / \mathrm{mL}$ (SUNIL et al., 2013).

Combretum has some secondary metabolites, such as saponins and alkaloids, that are involved in the anthelmintic effects (GITHIORI et al., 2006); in particular, C. leprosum Mart. was highlighted for its efficient leishmanicidal action in blood (LIMA et al., 2011).

In this context, this experiment aimed to evaluate the in vitro ovicidal and larvicidal activity of protein preparations obtained from C. fistula L. and C. leprosum Mart. leaves on the gastrointestinal nematodes of naturally infected goats.

\section{Materials and Methods}

\section{Extraction and obtaining protein preparations}

Specimens of $C$. fistula L. and C. leprosum Mart. were collected in the semiarid region of the Caatinga biome and submitted to taxonomic identification; they were cataloged under registration numbers 14.514 and 10.195 , respectively, in the Dárdano de Andrade Lima Herbarium, Department of Plant Sciences at the Semiarid Federal Rural University.

Following identification, the collected leaves were washed, dried, and ground. The obtained material was extracted in $0.15 \mathrm{M}$ of $\mathrm{NaCl}$ solution $10 \%(\mathrm{w} / \mathrm{v})$, followed by filtration and centrifugation to obtain the crude extract. The extracts were subjected to protein precipitation using increasing ammonium sulfate saturations: 30\%, 30\%-60\%, and 60\%-90\%. After each saturation, the samples were incubated under constant agitation, followed by centrifugation to obtain protein fractions (precipitated protein) referred to as F1, F2, and F3, respectively.

The samples were subjected to dialysis, protein quantification (LOWRY et al., 1951), and hemagglutinating activity assays in microtiter plates (CORREIA \& COELHO, 1995) to detect lectin activity. The specific hemagglutinating activity was determined by the hemagglutinating activity/protein concentration $(\mathrm{mg} / \mathrm{mL})$ ratio. Then, the samples were subjected to a dilution (in $0.15 \mathrm{M} \mathrm{NaCl}$ ) that was minimal enough to standardize the protein concentration of the C. fistula L. ( $4 \mathrm{mg} / \mathrm{mL})$ and C. leprosum Mart. $(20 \mathrm{mg} / \mathrm{mL})$ fractions.

\section{The selection of rural properties and the collection of fecal samples}

This study was conducted in the countryside of the city of Mossoró, Rio Grande do Norte, Northeastern Brazil, at south latitude coordinates of $5^{\circ} 11^{\prime} 15^{\prime}$, west longitudinal coordinates of $37^{\circ} 20^{\prime} 39^{\prime \prime}$, and at an altitude of $16 \mathrm{~m}$ in a predominantly semiarid climate; here, the average temperature is $27.4^{\circ} \mathrm{C}$, the rainy season is concentrated between summer seasons with irregular rainfalls. Feces were collected directly from the rectum of naturally infected goats; this was followed by the counting of eggs per gram of feces (EPG) (GORDON \& WHITLOCK, 1939; CHAGAS et al., 2011). Fecal samples from the animals of five different farms were collected in a pool for each farm. The selected animals had reached the end of 12 weeks of a residual effect period following their last deworming (COLES et al., 1992) and they exhibited a fecal pool with $\geq 100$ EPG of feces (CHAGAS et al., 2011), regardless of breed, gender, or animal class. All experiments were performed in accordance with the recommended procedures of the National Council for the Control of Animal Experimentation. The study was approved by the Ethics Commission on Animal Experimentation of the Semiarid Federal Rural University (number 23091.009318/2016-40).

\section{Egg-hatch test}

The recovery of nematode eggs was performed according to Hubert \& Kerboeuf (1992) methodology. The egg hatch test (EHT) was performed according to the methodology from Coles et al. (2006); a $100 \mu \mathrm{L}$ solution containing approximately 100 eggs and $400 \mu \mathrm{L}$ of protein fractions or control solutions was added in each well of 24-well plates. For each experiment, one plate contained the controls: negative (eggs in distilled water) and positive (eggs and Thiabendazole $32 \mu \mathrm{L} / \mathrm{mL}$ ), and another plate contained the assays with the protein fractions: T1 (eggs and F1), T2 (eggs and F2), and T3 (eggs and F3). The EHT assays were performed in quintuplicate with three replicates for each treatment, as well as with the control group. Two independent studies were performed. Each one evaluated the activity of the fractions of one of the plants, Cassia fistula or Combretum leprosum. The plates were incubated at $27^{\circ} \mathrm{C}$ for 48 hours, after which point Lugol's solution was added; then, the eggs and L1 (larval development stage 1) were counted and the egg-hatching inhibition percentage was determined in accordance with the following formula:

Egg hatching inhibition percentage $=\frac{\text { Unhatched eggs }}{\text { Unhatched eggs }+\mathrm{L1}} \times 100$

\section{Larval development test}

For the larval development test (LDT) (HUBERT \& KERBOEUF, 1992; BIZIMENYERA et al., 2006), 24-well plates were used containing approximately 100 eggs/well in $100 \mu \mathrm{L} ; 80 \mu \mathrm{L}$ of suspension containing lyophilized Escherichia coli (ATCC 9637; Sigma-Aldrich Co., St Louis, MO, USA), $10 \mu \mathrm{L}$ of amphotericin B (Sigma-Aldrich Co., St Louis, MO, USA), and $20 \mu \mathrm{L}$ of nutrient 
media were added. Then, $100 \mu \mathrm{L}$ of distilled water was added and the plates were incubated in an oven incubator for 48 hours. After incubation, $220 \mu \mathrm{L}$ of F1, F2, or F3 was added. In separate plates, the assay with the positive control (larvae suspension and ivermectin) and the negative control (larvae suspension and distilled water) were carried out. The tests were performed in five replicates. Two independent studies were performed. Each one evaluated the activity of the fractions of one of the plants, Cassia fistula or Combretum leprosum. The plates were incubated for 7 days, after which Lugol's solution was added to the wells; then, L1 and L3 (the third larval stage of development) were counted to calculate the percentage of larval development inhibition, in accordance with the following formula:

$$
\text { Larval development inhibition }=\frac{\mathrm{L} 1}{\mathrm{~L} 1+\mathrm{L} 3} \times 100
$$

\section{Statistical analysis}

The tests were conducted in a completely randomized design; for each test, there were 5 samples. Each experimental unit consisted of 100 eggs or larvae. The data were tabulated in an electronic spreadsheet and submitted to the Kruskal-Wallis test and Mann-Whitney pairwise comparations with Bonferroni correction, and significance level equal to $5 \%(\alpha=0.05)$. The data were expressed as the percentage inhibition ( \pm standard deviation), and the inhibition was represented as percentage of inhibition per milligram of protein.

\section{Results}

\section{Protein preparation characterization}

From the extraction processes, which were followed by salt fractionation, the protein fractions F1, F2, and F3 obtained from C. fistula L. and C. leprosum Mart. after dialysis exhibited protein contents of $5.06 \mathrm{mg} / \mathrm{mL}, 4.62 \mathrm{mg} / \mathrm{mL}$, and $5.53 \mathrm{mg} / \mathrm{mL}$, and $66.47 \mathrm{mg} / \mathrm{mL}, 54.55 \mathrm{mg} / \mathrm{mL}$, and $42.04 \mathrm{mg} / \mathrm{mL}$, respectively. These protein fractions from $C$. fistula L. and C. leprosum Mart. presented hemagglutinating activity (HA) titers of 64, 256, and 256 and $32,768,8,192$, and 8,192, respectively, revealing the presence of lectins. The specific HA (HA/protein concentration in $\mathrm{mg} / \mathrm{mL}$ ) in these samples was $12.64,55.41$, and 46.29 and 492.95, 150.19, and 194.88, respectively.

\section{Egg-hatching and larval development inhibition}

The results of the EHT and LDT using the Cassia fistula L. and Combretum leprosum Mart. protein fractions (F1, F2, and F3) (and compared to controls) are shown in Table 1 and 2. Through the EHT assays, all C. fistula L. protein fractions yielded the same percentage of egg-hatching inhibition (38\%), which was not statistically significantly different compared to the positive control. The EHT investigating the $C$. leprosum Mart. protein fractions F1, F2, and F3, revealed low egg-hatching inhibition percentages $(8 \%, 10 \%$, and $9 \%$, respectively), and these were
Table 1. Inhibitory effect of Cassia fistula L. protein fractions (F1, F2, and F3) on the egg-hatching test (EHT) and on the larval development test (LDT) of gastrointestinal nematodes in goat.

\begin{tabular}{lccc}
\hline \multicolumn{2}{c}{ Treatments } & $\begin{array}{c}\text { EHT (\%)* } \\
(\%)^{* *}\end{array}$ & $\begin{array}{c}\text { LDT (\%)* } \\
(\%)^{* *}\end{array}$ \\
\hline C. fistula & $\mathrm{F} 1$ & $38 \pm 15^{\mathrm{a}}$ & $61 \pm 14^{\mathrm{a}}$ \\
& $\mathrm{F} 2$ & $38 \pm 17^{\mathrm{a}}$ & $62 \pm 26^{\mathrm{a}}$ \\
\multirow{6}{*}{ Controls } & $\mathrm{F} 3$ & $38 \pm 17^{\mathrm{a}}$ & $69 \pm 23^{\mathrm{a}}$ \\
& $\mathrm{H}_{2} \mathrm{O}$ & $8 \pm 7^{\mathrm{b}}$ & $18 \pm 7^{\mathrm{b}}$ \\
& Thiabendazol & $30 \pm 15^{\mathrm{a}}$ & - \\
& Ivermectin & - & $81 \pm 11^{\mathrm{a}}$ \\
\hline
\end{tabular}

Notes: ${ }^{*}$ Inhibition $(\%) ;{ }^{* *}$ The values represent the mean \pm standard deviation (SD). F1, F2, and F3: protein fractions obtained by the saturation of plant extracts with ammonium sulfate (at 30\%, 30\%-60\%, and 60\%-90\%, respectively), followed by centrifugation and dialysis. Different letters indicate statistically significant differences $(P<0.05)$ when compared with the control.

Table 2. Inhibitory effect of Combretum leprosum Mart. protein fractions (F1, F2, and F3) on the egg-hatching test (EHT) and on the larval development test (LDT) of gastrointestinal nematodes in goat.

\begin{tabular}{lccc}
\hline \multicolumn{2}{c}{ Treatments } & $\begin{array}{c}\text { EHT (\%)* } \\
(\%)^{* *}\end{array}$ & $\begin{array}{c}\text { LDT (\%)* } \\
(\%)^{* *}\end{array}$ \\
\hline C. leprosum & $\mathrm{F} 1$ & $8 \pm 23^{\mathrm{a}}$ & $18 \pm 16^{\mathrm{a}}$ \\
& $\mathrm{F} 2$ & $10 \pm 21^{\mathrm{a}}$ & $16 \pm 9^{\mathrm{a}}$ \\
\multirow{4}{*}{ Controls } & $\mathrm{F} 3$ & $9 \pm 24^{\mathrm{a}}$ & $18 \pm 10^{\mathrm{a}}$ \\
& $\mathrm{H}_{2} \mathrm{O}$ & $4 \pm 3^{\mathrm{a}}$ & $13 \pm 3^{\mathrm{a}}$ \\
& Thiabendazol & $49 \pm 30^{\mathrm{b}}$ & - \\
& Ivermectin & - & $57 \pm 7^{\mathrm{b}}$ \\
\hline
\end{tabular}

Notes: ${ }^{*}$ Inhibition $(\%) ;{ }^{* *}$ The values represent the mean \pm standard deviation (SD). F1, F2, and F3: protein fractions obtained by the saturation of plant extracts with ammonium sulfate (at 30\%, 30\%-60\%, and 60\%-90\%, respectively), followed by centrifugation and dialysis. Different letters indicate statistically significant differences $(P<0.05)$ when compared with the control.

also not statistically significantly different when compared to the negative control $(P \geq 0.05)$.

The LDT results showed that the $C$. fistula L. protein fractions F1, F2, and F3 inhibited larval development (61\%, 62\%, and 69\%, respectively). There were no significant differences in the effect of the three preparations and that of the positive control, which characterized F1, F2, and F3 as efficient. The C. fistula L. protein fractions showed more intense larvicidal action than ovicidal action. Cuticular damage was observed, which was characterized by degeneration and retraction of the larval cuticle, which were suggested to be related to the larvicidal activity of the C. fistula L. preparations (Figure 1). The LDT performed with the C. leprosum Mart. preparations showed a low larval development inhibition percentage (18\% for F1 and F3, and 16\% for F2), which were not statistically different $(P \geq 0.05)$ when compared to the negative control.

\section{Discussion}

The results reinforce the potential ovicidal and larvicidal action that was already reported in species of the Cassia genus, as verified by Ademola \& Eloff (2011), in which $C$. alata extracts showed a 


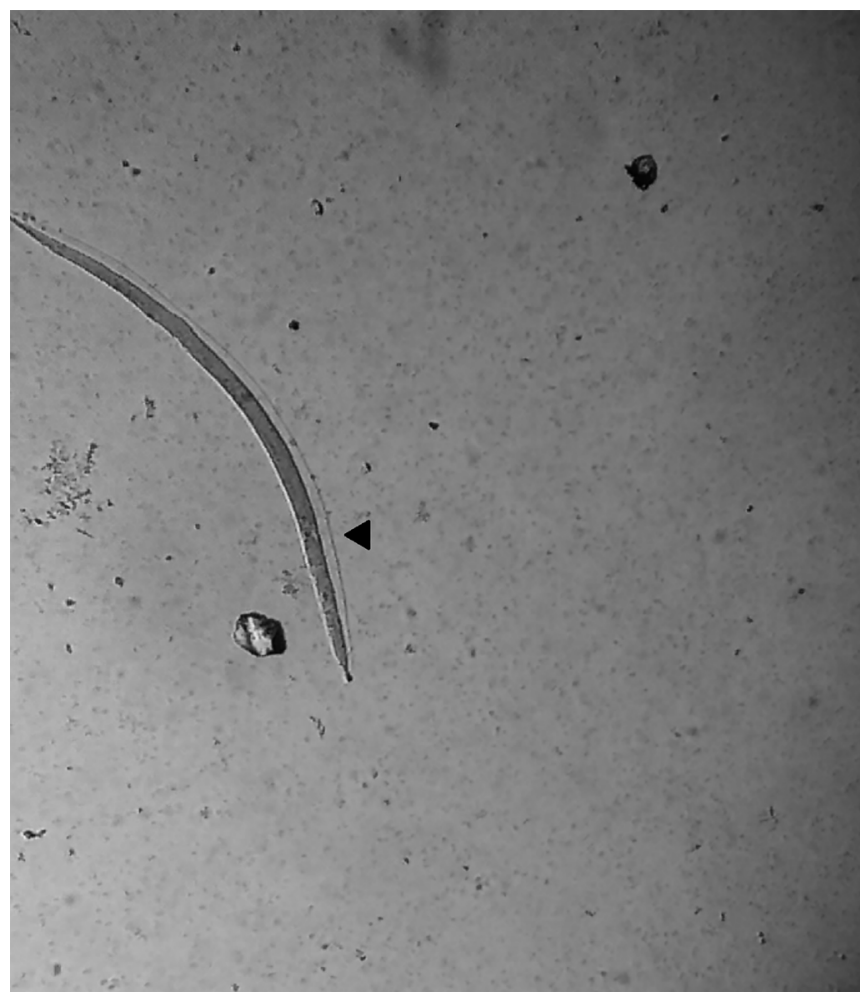

Figure 1. Larvicidal effect of protein extract preparations. The arrow indicates damage to the tegument accompanied by retraction of the nematode cuticle.

lethal dose $\left(\mathrm{LD}_{50}\right)$ of $0.191 \mathrm{mg} / \mathrm{mL}$ (in acetone) and $0.040 \mathrm{mg} / \mathrm{mL}$ (methanol:water) against $H$. contortus infective larvae. The ability of the preparations obtained from the C. fistula L. species to inhibit egg hatching may be associated with the presence of condensed tannins (BRÍGIDA et al., 2015). Tannins have promoted reductions in the emergence and development of nematodes in ruminants (IQBAL et al., 2007). However, it has been suggested that tannins act by a direct mechanism of action, which may affect the parasite's biological processes (HOSTE et al., 2006) or it may be related to egg-hatching inhibition. It may even have an indirect mechanism of action, where it may improve the host's protein usage and, consequently, its immune response (BUTTER et al., 2000).

The larvicide action promoted by $C$. fistula $\mathrm{L}$. protein preparations may be related to the presence of lectins, which are found in the preparations through the HA test; the larvicidal action is intrinsic to this class of proteins. Three possible mechanisms are suggested for these protein preparations: inhibition of the larvae's feeding behavior (which involves lectin's ability to recognize and bind to carbohydrates from the intestinal cells of larvae); interruption of larval migration (by the binding of lectins to the parasite's chemical sensors); and induction of visible cuticle damage, as observed in the extracts obtained from plants rich in cysteine proteases (RÍOS-DE ÁLVAREZ et al., 2012). However, additional studies are needed to elucidate the active component in the ovicidal and larvicidal action of $C$. fistula and its probable mechanism of action.

The results obtained with the $C$. leprosum Mart. protein preparations showed low ovicidal and larvicidal action. The ovicidal effect may be related to the presence of saponins, which may be present in the preparations; it may also be linked to the ability of this compound to destabilize membranes (such as those in eggs) and make them more permeable, thus preventing egg development (MANSFIELD et al., 1992). The action of C. leprosum Mart. preparations on parasite larvae may also be associated with lectins and their likely mechanisms of action, which have already been described.

The evaluation of protein preparations made from plant extracts as potential anthelmintics have allowed them to become incorporated in ethnobotanical concepts, which explore the knowledge accumulated by traditional communities, such as indigenous tribes (GARÍ, 2001), and it showed that the C. fistula L. preparations are an efficient alternative for parasite control. Since these preparations are obtained from renewable resources, are rapidly degradable, do not persist in the environment, and feature low production costs, their use is extremely advantageous when compared to synthetic drugs (ROEL, 2001).

It was concluded that protein preparations obtained from C. fistula L. and C. leprosum Mart. have ovicidal and larvicidal activity against goat endoparasites. Particular emphasis was placed on C. fistula L., which showed higher inhibition percentages. This study thus revealed that $C$. fistula $\mathrm{L}$. is a target species for the development of a new formulation that has plant-based protective benefits against gastrointestinal nematodes in goat. However, further studies are needed to evaluate in vitro and in vivo cytotoxicity.

\section{References}

Ademola IO, Eloff JN. Ovicidal and larvicidal activity of Cassia alata leaf acetone extract and fractions on Haemonchus contortus: In vitro studies. Pharm Biol 2011; 49(5): 539-544. http://dx.doi.org/10.3109/1388020 9.2010.526948. PMid:21501100.

Albuquerque UP, Medeiros PM, Almeida ALS, Monteiro, JM, Lins EMF No, Melo JG, et al. Medicinal plants of the caatinga (semi-arid) vegetation of NE Brasil: a quantitative approach. J Ethnopharmacol 2007; 114(3): 325-354. http://dx.doi.org/10.1016/j.jep.2007.08.017. PMid:17900836.

Bizimenyera ES, Githiori JB, Eloff JN, Swan GE. In vitro activity of Peltophorum africanum Sond. (Fabaceae) extracts on the egg hatching and larval development of the parasitic nematode Trichostrongylus colubriformis. Vet Parasitol 2006; 142(3-4): 336-343. http://dx.doi.org/10.1016/j. vetpar.2006.06.013. PMid:16899339.

Brigida SSS, Lins ALFA, Nascimento ME, Xavier Júnior SR, Souza HJR. Anatomia e histoquímica das folhas de Cassia fistula L. (LeguminosaeCaesalpinioideae). Enciclopédia Biosfera 2015; 11(21): 175-189.

Butter NL, Dawson JM, Wakelin D, Buttery PJ. Effect of dietary tannin and protein concentration on nematode infection (Trichostrongylus colubriformis) in lambs. J Agric Sci 2000; 134(1): 89-99. http://dx.doi. org/10.1017/S0021859699007315.

Chagas ACS, Niciura SCM, Molento MB. Manual prático: metodologias de diagnóstico da resistência e de detecção de substâncias ativas em parasitas de ruminantes. Brasília: Embrapa; 2011. 153 p.

Coles GC, Bauer C, Borgsteede FHM, Geerts S, Klei TR, Taylor MA, et al. World Association for the Advancement of Veterinary Parasitology (W.A.A.V.P.) methods for the detection of anthelmintic resistance in nematodes of veterinary importance. Vet Parasitol 1992; 44(1-2):35-44. 
Coles GC, Jackson F, Pomroy WE, Prichard RK, von Samson-Himmelstjerna $\mathrm{G}$, Silvestre A, et al. The detection of anthelmintic resistance in nematodes of veterinary importance. Vet Parasitol 2006; 136(3-4): 167-185. http:// dx.doi.org/10.1016/j.vetpar.2005.11.019. PMid:16427201.

Correia MTS, Coelho LCBB. Purification of a glucose/mannose specific lectin, Isoform 1, from seeds of Cratylia mollis Mart. (Camaratu bean). Appl Biochem Biotechnol 1995; 55(3): 261-273. http://dx.doi.org/10.1007/ BF02786865. PMid:8579345.

Garí JA. Biodiversity and indigenous agroecology in Amazonia: the indigenous peoples of Pastaza. Etnoecológica 2001; 5(7): 21-37.

Githiori JB, Athanasiadou S, Thamsborg SM. Use of plants in novel approaches for control of gastrointestinal helminths in livestock with emphasis on small ruminants. Vet Parasitol 2006; 139(4): 308-320. http:// dx.doi.org/10.1016/j.vetpar.2006.04.021. PMid:16725262.

Gordon HM, Whitlock HV. A new technique for counting nematode eggs in sheep faeces. J Counc Sci Ind Res 1939; 12(1): 50-62.

Govindarajan M, Jebanesan A, Pushpanathan T. Larvicidal and ovicidal activity of Cassia fistula Linn. leaf extract against filarial and malarial vector mosquitoes. Parasitol Res 2008; 102(2): 289-292. http://dx.doi. org/10.1007/s00436-007-0761-y. PMid:17989995.

Hoste H, Jackson F, Athanasiadou S, Thamsborg SM, Hoskin SO. The effects of tannin-rich plants on parasitic nematodes in ruminants. Trends Parasitol 2006; 22(6): 253-261. http://dx.doi.org/10.1016/j. pt.2006.04.004. PMid:16632404.

Hubert J, Kerboeuf D. A microlarval development assay for the detection of anthelmintic resistance in sheep nematodes. Vet Rec 1992; 130(20): 442-446. http://dx.doi.org/10.1136/vr.130.20.442. PMid:1621342.

Iqbal Icbal Z, Sarvar M, Jabbar A, Ahmed S, Nisa M, Sajid MS, et al. Direct and indirect anthelmintic effects of condensed tannins in sheep. Vet Parasitol 2007; 144(1-2): 125-131. http://dx.doi.org/10.1016/j. vetpar.2006.09.035. PMid:17097807.

Kashiwada Y, Iizuka H, Yoshioka K, Chen R-F, Nonaka G, Nishioka I. Tannins and related compounds. XCIII. Occurrence of enantiomeric proanthocyanidins in the leguminosae plants, Cassia fistula L. and C. javanica L. Chem Pharm Bull (Tokyo) 1990; 38(4): 888-893. http:// dx.doi.org/10.1248/cpb.38.888.

Lima ER, Moreira LS, Facundo VA, Silva-Jardim I, Teles CBG. Avaliaçáo da bioatividade do extrato etanólico e triterpeno lupano obtidos de Combretum leprosum contra microorganismos. Saber Cient 2011; 3(1): 53-69.

Lowry OH, Rosebrough NJ, Farr AL, Randall RJ. Protein measurement with the folin phenol reagent. J Biol Chem 1951; 193(1): 265-275. PMid:14907713.

Mansfield LS, Gamble HR, Fetterer RH. Characterization of the eggshell of Haemonchus contortus - I. Structural components. Comp Biochem Physiol B 1992; 103(3): 681-686. http://dx.doi.org/10.1016/03050491(92)90390-D. PMid:1458842.

Marie-Magdeleine C, Udino L, Philibert L, Bocage B, Archimede H. In vitro effects of Musa x paradisiaca extracts on four developmental stages of Haemonchus contortus. Res Vet Sci 2014; 96(1): 127-132. http://dx.doi. org/10.1016/j.rvsc.2013.12.004. PMid:24382490.

Molento MB, Fortes FS, Pondelek DAS, Borges FA, Chagas ACC, Torres-Acosta JFF, et al. Challenges of nematode control in ruminants: Focus on Latin America. Vet Parasitol 2011; 180(1-2): 126-132. http:// dx.doi.org/10.1016/j.vetpar.2011.05.033. PMid:21684690.

Ríos-de Álvarez L, Jackson F, Greer A, Bartley Y, Bartley DJ, Grant $\mathrm{G}$, et al. In vitro screening of plant lectins and tropical plant extracts for anthelmintic properties. Vet Parasitol 2012; 186(3-4): 390-398. http:// dx.doi.org/10.1016/j.vetpar.2011.11.004. PMid:22130336.

Roel AR. Utilização de plantas com propriedades inseticidas: uma contribuição para o Desenvolvimento Rural Sustentável. Rev Int Desenvol Local 2001; 1: 43-50.

Sunil AR, Amithamol KK, Juliet S, Nair SN, Ajithkumar KG, Soorya VC, et al. Acaricidal effect of Cassia fistula Linn. leaf ethanolic extract against Rhipicephalus (Boophilus) annulatus. Trop Biomed 2013; 30(2): 231-237. PMid:23959488. 